\title{
Pensonomonoor
}

2018, vol. 80, 81-90

http://dx.doi.org/10.12657/denbio.080.008

\author{
Antonín Martiník, Matúš Sendecký, Josef Urban
}

\section{Survival and early growth of silver fir and pioneer species on two sites in nurse crop regeneration systems in the Czech Republic}

\author{
Received: 28 June 2018; Accepted: 5 November 2018
}

\begin{abstract}
Silver fir used to be one of the most important tree species in the Czech forests until the $19^{\text {th }}$ century. Large scale clearcuts, which nowadays occur after the salvage logging of Norway spruce due to wind of bark-beetle attacks are unfavourable for the artificial regeneration of a fir. Growth of silver fir and three pioneer species was studied during first three years in a nurse crop system established after forest disturbance events. Five-years-old containerized silver fir seedlings were planted in autumn 2014 with silver birch, alder or aspen with and without nurse crops (control plot) on two localities (Tornádo and Rakovec). The Tornádo site represents natural conditions of Central European forest (Fageta typica) type on a haplic cambisols and favourable soil water regime, while Rakovec site a Querco-Abietetum forest type on a haplic stagnosols, which was periodically waterlogged. Silver fir grew best in admixture with silver birch which significantly promoted the height increment of the firs on both localities and improved the fir survival rate at one of the sites. The lower mortality and faster growth of both silver fir and pioneers were observed on Tornádo site where $92 \%$ and $100 \%$ of the silver fir trees survived under the birch and aspen cover, respectively, while $93 \%$ of planted firs survived in the open area. Only $93 \%$ and $67 \%$ of silver firs survived on the Rakovec site with same two pioneer species, respectively and $73 \%$ in the open area. After three years the highest height increment of silver fir was observed under silver birch, where trees were by $20 \mathrm{~cm}$ and $11 \mathrm{~cm}$ taller at Tornádo and Rakovec sites, than on the control plots, respectively. Aspen and alder had no significant effect on the height increment of a silver fir at any of the study sites. The shelter of nurse crops had no effect on the air temperature. The artificial regeneration of a climax silver fir and a pioneer silver birch was beneficial on Tornádo sites. On the other hand, there should be a delay between the regeneration of silver birch and underplanting of fir on the waterlogged sites.
\end{abstract}

Keywords: disturbance, silviculture, soil conditions, silver birch, forest regeneration

Addresses: A. Martiník, Faculty of Forestry and Wood Technology, Mendel University in Brno, 61300 Brno, Czech Republic, e-mail: antonin.martinik@mendelu.cz M. Sendecký, Faculty of Forestry and Wood Technology, Mendel University in Brno, 61300 Brno, Czech Republic, e-mail: msendecky@gmail.com J. Urban, Faculty of Forestry and Wood Technology, Mendel University in Brno, 61300 Brno, Czech Republic; Siberian Federal University, Krasnoyarsk, Russia, e-mail: josef.urban@email.cz 


\section{Introduction}

Global climatic changes, new scientific knowledge and human needs lead to changes in forest management and tree species composition (Schelhaas, 2008; Čermák \& Holuša, 2011; Hlásny et al., 2014; Brang et al., 2014). In the conditions of Central Europe, forest management is concerned with the transformation of Norway spruce (Picea abies (L.) H. Karst.) monocultures into more diverse forests structure with close-to nature tree species composition (Fanta, 1997; Spiecker et al., 2004). The transformation of existing forests is realized using a range of silvicultural treatments: thinning, shelterwood methods, underplanting or supported advanced regeneration, to name a few (Cameron et al., 2001; Pommerening, 2006; Schütz, 2011; O'Hara, 2014). The transformation process based on pioneer species and a succession processes is recommended on bare land (afforestation) or in areas affected by large disturbances. At the same time, the wider use of pioneer species as a first step of the forest regeneration process is considered as a close-to nature regeneration method (Pommerening \& Murphy, 2004; Martiník et al., 2014).

The pioneer species are better adapted to inhabit large disturbance areas and bare lands without shelter; they grow fast and their life is rather short (Brzeziecki \& Kienast, 1994; Ellenberg, 2009). As a consequence of their short life, the combination with climax tree species may provide better possibilities to establish more diverse and consequently more stable forests during forest regeneration. The regeneration method combining the pioneer and climax species is called 'nurse crop' (Seitschek, 1991; Pommerening \& Murphy, 2004), where climax species are introduced later or at the same time with pioneer species. The method is used for a wide range of species. As the pioneer species, the most commonly used are birch (Betula pendula Roth.), alder (Alnus glutinosa (L.) Gaertn.) or aspen (Populus tremula L.). Sesile oak (Quercus petraea (Matt) Liebl.), European beech (Fagus sylvatica L.), and silver fir (Abies alba Mill.) are the considered climax species in the region of Central Europe (Seitschek, 1991; Unselt \& Bauhus, 2012).

Silver fir (Abies alba Mill.) was an important species in Central European forests, but its proportion decreased during the $20^{\text {th }}$ century (Korpel' \& Vinš, 1965; Málek, 1983; Spiecker et al., 2004; Dobrowolska et al., 2017). During the $18^{\text {th }}$ and $19^{\text {th }}$ centuries, regeneration of silver fir has been promoted due to massive used of beech wood for the charcoal burning, forest litter collection, and cattle grazing. Later, the proportion of fir decreased, often due to unsuitable forest management, overbrowsing and air pollution (Elling et al., 2009; Vrška et al., 2009; Dobrowolska et al.,
2017). Although the natural composition (share of total forest area) of silver fir in the Czech Republic used to be more than 20\% (Kantor, 2001; Šindelář \& Frýdl, 2005), today it is only 1\% (Zpráva, 2016).

As a native, shade tolerant, deeply rooting and highly productive species, fir is considered a prospective and economically valuable species in the Central Europe (Dobrowolska et al., 2017; Kacálek et al., 2017; Beljan et al., 2018). It is relatively drought tolerant which is an important characteristics in perspective of the climatic change (Hlásny et al., 2011; Gazol \& Camarero, 2016). Appropriate management of mixture of silver fir with beech is, however, a question which is discussed in the current silviculture (Čater \& Levanič, 2013; Čater et al., 2014).

In most areas, mature seed trees are missing, therefore the artificial regeneration is the only feasible method to preserve and increase its share in the tree species composition (Vaněk \& Mauer, 2014). Due to the sensitivity of the silver fir to climatic conditions, the suggested artificial regeneration method is underplanting or planting in small gaps (Korpel' \& Vinš, 1965). In large clearing areas without shelter, the regeneration of silver fir is conducted via preparatory stands (Hurt \& Mauer, 2016). Fencing is necessary to eliminate high pressure of game (i.e. grazing), which is often limiting factor for its successful regeneration (Korpel’ \& Vinš, 1965; Martiník \& Dušek, 2015; Motta, 1996; Senn \& Suter, 2003). The planting of fir under existing preparatory stands is preferred, however the simultaneous regeneration of silver fir and pioneer species is also possible (Pommerening \& Murphy, 2004).

The working hypothesis of this study was that early shelter of pioneer species as a nurse crop may provide suitable conditions for survival and growth of planted silver fir in the early stage of forest regeneration. The specific aim of this study was: a) to compare the survival rate and early height growth of planted fir with other pioneer tree species on different sites; b) to analyse differences in survival and growth of planted silver fir, together with different species - birch, aspen, (alder) and sites without pioneer species (mono-specific control plots) and c) to compare the microclimate (specifically air temperature) between a clearing and the understorey of the nurse crops.

\section{Material and methods}

Two experimental sites Tornádo and Rakovec were selected for the study (Table 1). Experimental plots at both sites were established after windthrow calamities, which came in the 2013 vegetation season. The mature stands in both cases were old conifer, predominantly Norway spruce stands. Clearings of the 
Table 1. Characteristics of Tornádo and Rakovec experiment sites (Klimatická změna, 2018)

\begin{tabular}{lcc}
\hline & Tornádo & Rakovec \\
\hline Coordinates GPS & $50^{\circ} 5^{\prime} 11.072 \mathrm{~N}$ & $49^{\circ} 19^{\prime} 31.210 " \mathrm{~N}$ \\
& $17^{\circ} 39^{\prime} 46.196 " \mathrm{E}$ & $16^{\circ} 47^{\prime} 21.755^{\prime \prime} \mathrm{E}$ \\
Altitude [m] a.s.1 & 450 & 450 \\
Mean temperature $\left[{ }^{\circ} \mathrm{C}\right]$ & $7.1-9.0$ & $7.1-9.0$ \\
Precipitation $[\mathrm{mm}]$ & $601-700$ & $551-650$ \\
Soil type & haplic cambisol & haplic stagnosol \\
\hline
\end{tabular}

size of 15 ha in case of Tornádo and 1.5 ha in case of Rakovec occurred after wind calamities at both sites, as all trees were removed and only stumps were left in the areas affected by disturbances.

Although the climatic conditions were similar, there were differences between the sites in forest type and in the soil conditions (Table 1). The potential vegetation at Tornádo was Fageta typica and at Rakovec site Querco-Abietetum (Zlatník, 1976; Ellenberg, 2009). According to the definition of IUSS (2014), the soil type at Tornádo was a haplic cambisol with favourable moisture regime, while at the Rakovec site the haplic stagnosol with periodic influence of water. According to forest type classification more favourable conditions regarding nutrient availabilities and soil aeration are expected within Tornádo site (Viewegh et al., 2003; Ellenberg, 2009). The differences in soil condition between sites lead to a change in grass-herbal vegetation. In Rakovec, Calamagrostis epigejos (L.) Roth. was the completely dominating grass species. A lower herb cover was observed in Tornádo, where the dominant species was Rubus spp.

Four sub-plots were established within Rakovec and three within Tornádo sites in autumn 2014. The sub-plots included nurse crops of the pioneer species with silver fir planted at the same time and mono-specific (control) sub-plots, with silver fir artificially regenerated without the shelter of the pioneer species. Three species of nurse crop were used on various sub-plots: silver birch (Birch), aspen poplar (Aspen) and black alder (Alder); the last one was planted only in Rakovec. To indicate the sub-plots, the index I was used for Tornádo (Birch I, Aspen I, Control I) and the index II for Rakovec (Birch II, Aspen II, Alder II, Control II). The sub-plots were square shaped with an edge length of $20 \mathrm{~m}$. The buffer distances between two sub-plots were two or three meters. All sub-plots were fenced immediately after planting.

The seedlings were planted (hole planting method) before the beginning of the growing season in spring 2015. The seedlings of all planted pioneer species on the respective sub-plots were similar in height, ranging between $70-120 \mathrm{~cm}$ in various species. The seedlings of silver fir were the same in terms of origin (Hercynian region) and characteristics for

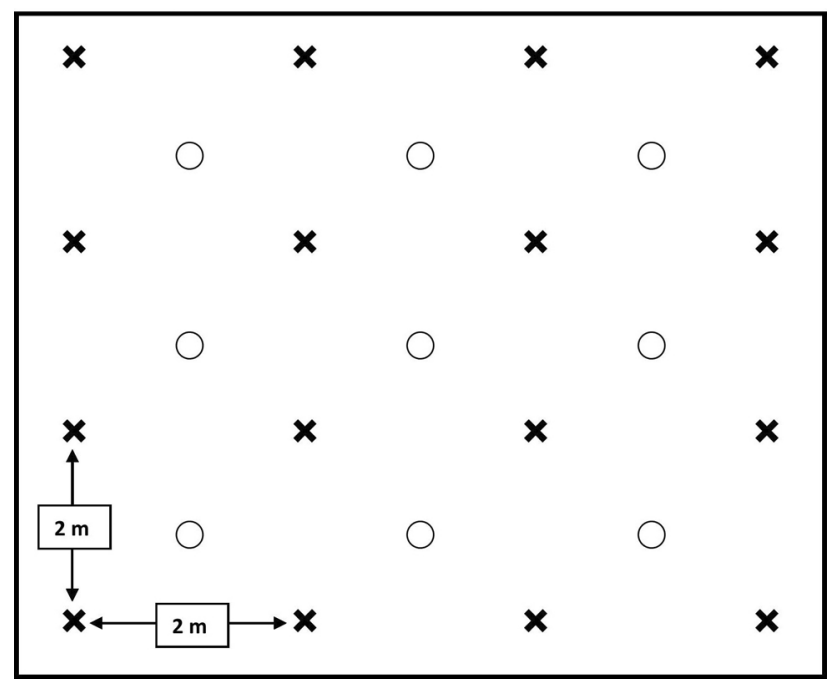

Fig. 1. Nurse crops design used in sub-plots. Row to row and plots to plants distance between two pioneers and two silver fir were the same $-2 \mathrm{~m}$ $x$ - Pioneer species (Birch, Aspen, Alder). $\circ-$ Silver fir.

all sub-plots. Containerized silver fir seedlings were 5 years old with their height ranging from $15-25 \mathrm{~cm}$.

The row-to-row and also plant-to-plant distances between the individual pioneer $(\times)$ and silver fir $(0)$ trees were $2 \mathrm{~m}$ in every case (Fig. 1 ). The spacing of silver fir in the mono-specific sub-plots was $2 \times 1 \mathrm{~m}$. Stand density remained constant during the observed period because the trees that had died were replaced and were not included in the analyses. To protect the seedlings against ground vegetation, manual individual mulching was practiced on all plots.

The inventory and measurement of seedlings were performed at the end of each growing seasons (2015, 2016 and 2017). The number of measured seedlings within sub-plots ranged between 47-84 in silver firs and between $56-112$ in pioneer species. The boundary trees were neglected and were not measured. For each sub-plot, the seedling survival rate (SR) was calculated according to the formula: SR $=$ (number of living seedlings/number of planted seedlings in 2014) $\times 100$.

At the same time, the height and annual height increment of silver fir, and height of pioneer species was measured.

Air temperature was measured at both plots - on the Control I and II sub-plots, under the birch understory on Tornádo (Birch I) and under the aspen on Rakovec (Aspen II) at a height of $50 \mathrm{~cm}$ above the soil. The Minikin TH which is a combined temperature and humidity sensor with built-in datalogger (EMS Brno, Czech Republic) was used (with its radiation shelter). Data were measured from $1^{\text {st }}$ February 2016 until $31^{\text {st }}$ December 2017, every 10 minutes and 60 -minute means were stored in the memory of a datalogger. 


\section{Data analyses}

Two-way analysis of variance (ANOVA) was used to detect significant differences in height growth of the seedlings between site (plots) and treatments (sub-plots, various nurse crops). Differences between all the means were evaluated by Tukey's test. Significant differences between the same pioneer species on the two plots (I, II) were analysed using t-tests according to the data distribution. All data analyses were conducted in $\mathrm{R}$ (version 3.4.2, R Core Team 2017, Vienna, Austria).

\section{Results}

\section{Silver fir}

High SR of silver fir was found in all sub-plots of Tornádo and a low SR in most of the sub-plots of Rakovec. Only in the case of the sub-plot Birch II, the SR of silver fir was similar to that in sub-plot Birch I (92\% and 93\%; see Table 2).

Both site and the nurse crop affected the height growth increment of silver fir (Table 3; Fig. 2). Best

Table 2. Survival rate of selected tree species within subplots at Tornádo and Rakovec sites after three growing seasons

\begin{tabular}{lcccccc}
\hline & \multicolumn{5}{c}{ Survival rate (\%) } \\
\cline { 2 - 7 } Sub-plots & \multicolumn{5}{c}{ Tornádo } & \multicolumn{5}{c}{ Rakovec } \\
\cline { 2 - 7 } & 2015 & 2016 & 2017 & 2015 & 2016 & 2017 \\
\hline Control & 100 & 97.1 & 97.1 & 95.5 & 84.1 & 72.7 \\
Birch & 100 & 98.6 & 91.8 & 100 & 92.9 & 92.9 \\
Aspen & 100 & 100 & 100 & 84.5 & 73.8 & 67.9 \\
Alder & $\times$ & $\times$ & $\times$ & 100 & 95.7 & 87.2 \\
\hline \multicolumn{6}{c}{ Pioneer species } \\
\hline Birch & 100 & 87.8 & 85 & 96.6 & 39.7 & 36.2 \\
Aspen & 93.9 & 91.9 & 89 & 92.6 & 85.1 & 66.1 \\
Alder & $\times$ & $\times$ & $\times$ & 97.2 & 97.2 & 95.8 \\
\hline
\end{tabular}

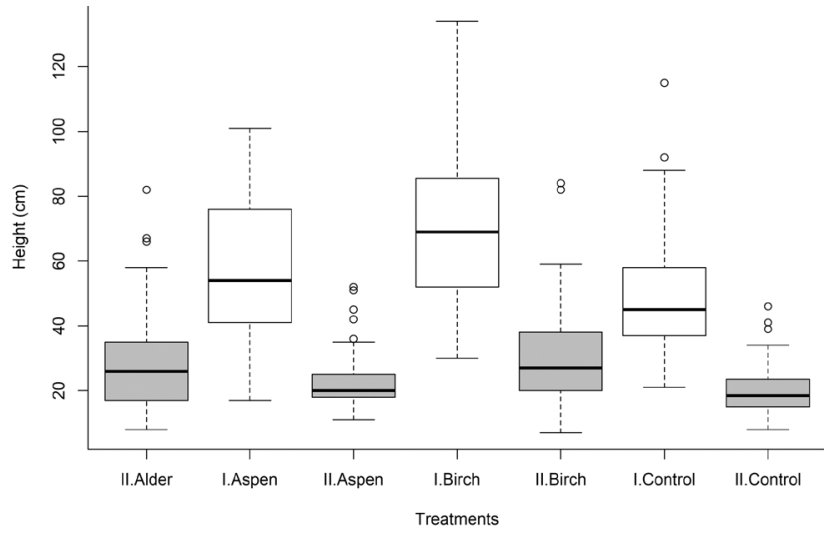

Fig. 2. Height of silver fir on Tornádo (Treatments - I) and Rakovec (Treatments - II) sites 3 years after planting

height growth was achieved under the cover of the silver birch, on both sites. After the three years the silver fir was taller under the birch than on control sub-plots by $20 \mathrm{~cm}$ and $11 \mathrm{~cm}$ at Tornádo and Rakovec sites, respectively. Silver fir admixed with other pioneer tree species did not significantly differ neither from the control plot nor from the silver birch plot (with the exception of Aspen I) after three year of the experiment, even though they were taller than on the control. Differences in height growth occurred already from the first year after planting. After the first year, the height of silver fir growing in Birch I and Aspen I was significantly higher than that on Control I. On Rakovec sites, after the first growing season, the height of silver fir was comparable to the silver fir planted in Control I only in sub-plots Alder and Birch. In Tornádo, also after the second growing season, there were differences detected in the height of the silver fir growing under the shelter of the nurse crops and in the Control sub-plot.

The silver fir trees grew better at Tornádo than at Rakovec site. The trees on Rakovec site were shorter than in Tornádo by $30 \mathrm{~cm}$ on the control plot and by $39 \mathrm{~cm}$ under the birch after the three years. The

Table 3. Mean height of pioneer species and silver fir seedlings outplanted on the sub-plots of Tornádo and Rakovec plots at the end of each of the three growing seasons

\begin{tabular}{|c|c|c|c|c|c|c|}
\hline \multirow{3}{*}{ Sub-plots } & \multicolumn{6}{|c|}{ Height $(\mathrm{cm})$} \\
\hline & \multicolumn{3}{|c|}{ Tornádo } & \multicolumn{3}{|c|}{ Rakovec } \\
\hline & 2015 & 2016 & 2017 & 2015 & 2016 & 2017 \\
\hline & \multicolumn{6}{|c|}{ Seedlings of pioneer species } \\
\hline Birch & $140.7 \pm 30.0 \mathrm{a}$ & $251.9 \pm 44.1 \mathrm{a}$ & $348.1 \pm 55.1 \mathrm{a}$ & $125.6 \pm 20.1 b$ & $128.2 \pm 35.7 b$ & $158.2 \pm 48.6 \mathrm{~b}$ \\
\hline Aspen & $117.4 \pm 25.2 \mathrm{a}$ & $186.4 \pm 63.8 \mathrm{a}$ & $223.1 \pm 76.4 a$ & $93.5 \pm 27.2 b$ & $109.2 \pm 27.5 b$ & $117.0 \pm 33.2 b$ \\
\hline \multirow[t]{2}{*}{ Alder } & $\times$ & $\times$ & $\times$ & $108.3 \pm 18.8$ & $171.4 \pm 34.7$ & $234.7 \pm 49.2$ \\
\hline & \multicolumn{6}{|c|}{ Seedlings of silver fir } \\
\hline Control & $21.6 a$ & $36.5 a$ & $49.9 a$ & $-4.2 \mathrm{~d}$ & $-20.8 c$ & $-29.7 c$ \\
\hline Birch & $+5.5 b$ & $+9.9 b$ & $+19.6 b$ & $+0.5 \mathrm{a}$ & $-10.5 d$ & $-19.0 \mathrm{~d}$ \\
\hline Aspen & $+4.9 c$ & $+5.2 b$ & $+7.9 \mathrm{a}$ & $-3.1 \mathrm{e}$ & $-18.1 c$ & $-27.2 \mathrm{~cd}$ \\
\hline Alder & $\times$ & $\times$ & $\times$ & $+0.7 \mathrm{a}$ & $-12.1 \mathrm{de}$ & $-21.2 \mathrm{~cd}$ \\
\hline
\end{tabular}

Values marked with different letters are significantly different. 
differences in height growth of silver fir seedlings were supported by the magnitude and trend of the annual increments of these species. The progressive increase in the annual increment of fir in Tornádo was in the contrary to the stable and low increment of the planted fir seedlings detected in Rakovec (Fig. 3).

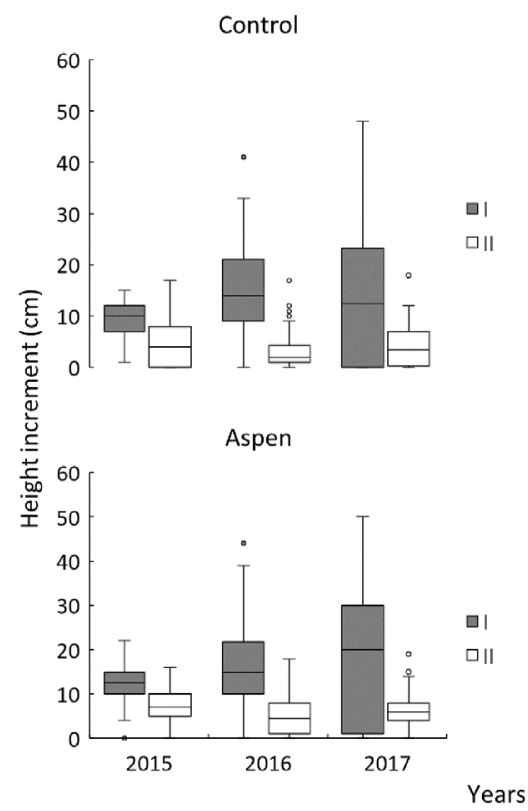

\section{Pioneer species}

The survival rate (SR) of nurse crop varied between the sites and the species of a nurse crop. The lowest survival rate of pioneer species at the end of the third year after planting (Table 2) was in Rakovec site, where it was $66 \%$ for aspen and only $36 \%$ for birch. The SR of the nurse trees at Tornádo site was

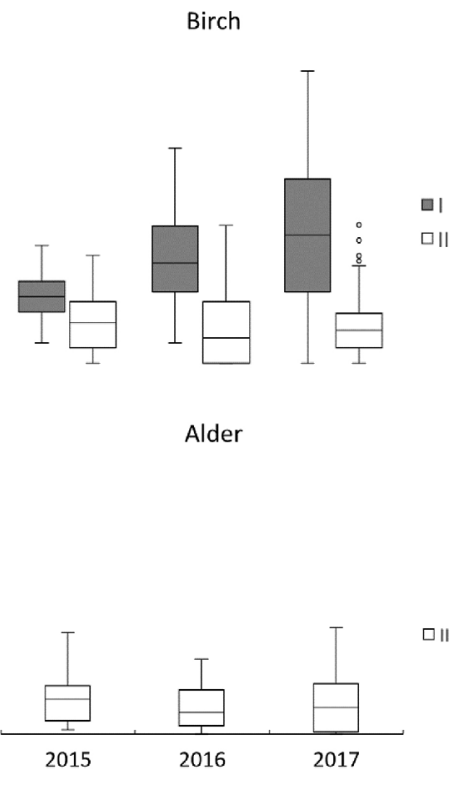

Fig. 3. Height increment of silver fir on Tornádo (I) and Rakovec (II) sites without any nurse crops (Control) and in mixture with various nurse crops during observed period

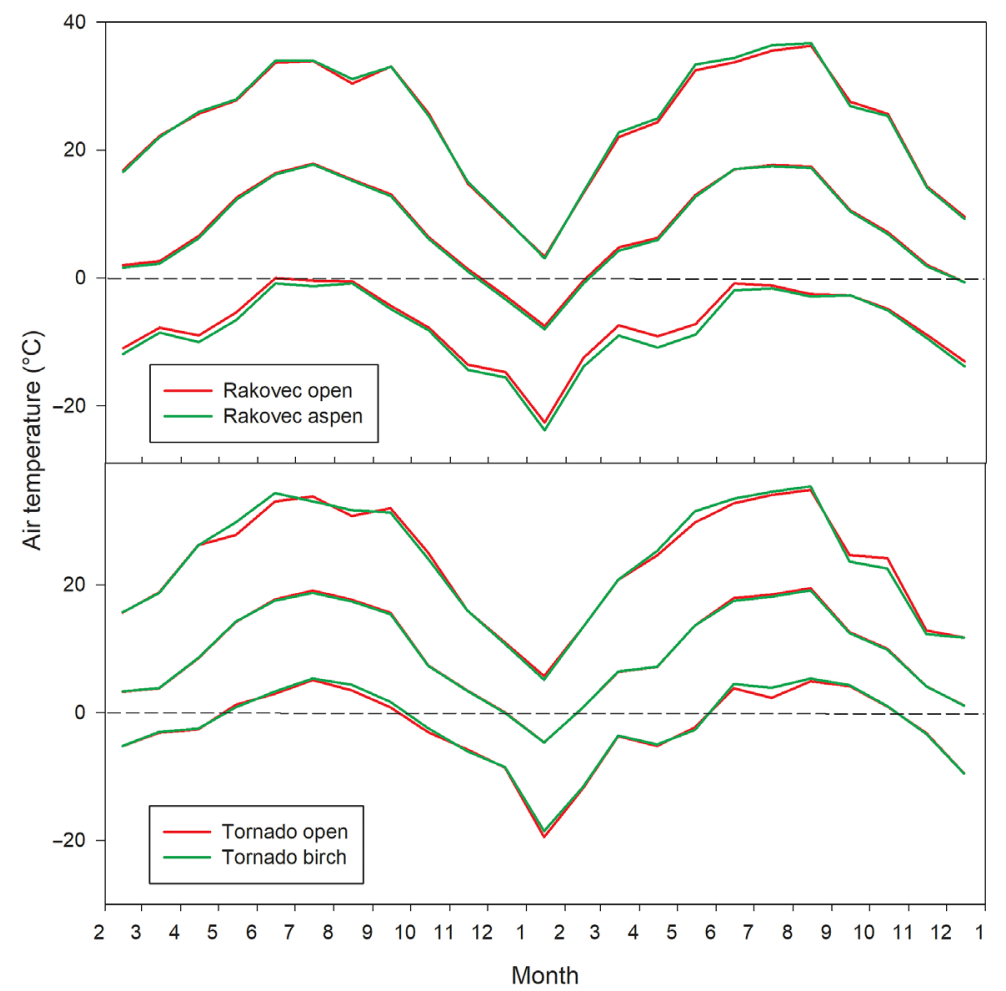

Fig. 4. Minimal (lower lines), maximal (upper lines) and average (middle lines) monthly mean temperatures at Rakovec site (upper panel) and Tornádo site (lower panel). Red: open plots, green: understorey of aspen and birch, respectively 
over $85 \%$ for both species. The highest SR (96\%) was found for alder, which was planted only in Rako$v e c$. Also, this results revealed that conditions of the Rakovec site was not optimal for artificial regeneration (planting) of birch and aspen.

The differences in the heights of the pioneer species between Tornádo and Rakovec were obvious and significant during all three years (Table 3 ). At the end of the third vegetation season, the average birch in Tornádo was by $190 \mathrm{~cm}$ taller than in Rakovec $(p<0.0001)$. In the case of aspen, these differences were smaller: in average $106 \mathrm{~cm}(\mathrm{p}<0.0001)$. Although the heights of birch and aspen seedlings at the time of planting were similar, birch overgrew aspen by $125 \mathrm{~cm}$ in Tornádo and by $41 \mathrm{~cm}$ in Rakovec during the observed periods (Table 3 ).

\section{Microclimate}

The mean air temperatures in the two years 2016 2017 at the Tornádo sub-plots were 9.1 and $9.0^{\circ} \mathrm{C}$ at the open (Control I) plot and under the birch (Birch I), respectively (Fig. 4). The mean air temperatures at the Rakovec sub-plots for the same period were 7.5 and $7.2^{\circ} \mathrm{C}$ at the open sub-plot (Control II) and under the aspen (Aspen II), respectively. The minimum air temperatures at the Tornádo site were -19.4 and $-18.5^{\circ} \mathrm{C}$ at Control I and under birch (Birch I), respectively. The minimum air temperatures at Rakovec for the same period were -22.6 and $-23.8^{\circ} \mathrm{C}$ at Control II and under aspen (Aspen II), respectively. The maximum air temperatures at the Tornádo subplots were 34.9 and $35.4^{\circ} \mathrm{C}$ at Control I and under birch (Birch I), respectively. The maximum air temperatures at Rakovec for the same period were 36.3 and $36.7^{\circ} \mathrm{C}$ at Control II and under aspen (Aspen II), respectively. Neither of the shelters was able to mitigate the effect of late frost. The minimum temperature in May occurred on $10^{\text {th }}$ May 2017. The minimum air temperatures at the Tornádo sub-plot were -2.3 and $-2.7^{\circ} \mathrm{C}$ at Control I and under birch (Birch I), respectively. The minimum air temperatures at the Rakovec sub-plot for the same period were -7.2 and $-8.8^{\circ} \mathrm{C}$ at Control II and under aspen (Aspen II), respectively.

\section{Discussion}

Survival rate of the planted silver fir under the nurse crops of various tree species at two different localities was affected both by the conditions at a specific locality and by the nurse crop. The effect of locality on the survival of a silver fir might be a result of different soil and microclimate conditions. Even though the silver fir was an important component of native forest in the region of both Tornádo and Rakovec research sites, the potential vegetation on Tornádo (Fageta typica) and Rakovec (Querco-Abietetum) assume different proportions of this species in native forest (Zlatník, 1976; Ellenberg, 2009). In a natural species composition, there used to be a higher share of silver fir at Rakovec than at Tornádo sites. Our results suggest that planted silver fir showed lower mortality and faster growth at Tornádo, which represented the site with favourable water soil regime compared to Rakovec plots, which was periodically naturally influenced by water in the soil. Both experimental sites were established in clearings after the wind calamity events. Conditions on a clearing completely differ from the ones below forest stands (Poleno \& Vacek, 2007). Differences in soil moisture under a forest canopy and in the open are larger and also more dangerous for regeneration in conditions similar to Rakovec after the removal of an old transpiring forest (Plíva \& Průša, 1969; Dube \& Plamondon, 1995). This should lead to a higher mortality of planted silver fir in Rakovec compared to Tornádo site. Even though the mortality of the silver fir was higher in Rakovec than in Tornádo, the mortality of other species was higher there, too.

Lower competition pressure of the determining species for middle altitudes of Central Europe beech - therefore allowed for higher proportion of silver fir at Querceto-Abietum sites (i.e. Rakovec) (Ellenberg, 2009). Also, lower nutrients and aeration of soil can be expected on Rakovec plot (Viewegh et al., 2003; Ellenberg, 2009).

Generally, conditions in the open without shelter of mature trees are not favourable for regeneration of shade tolerates (climax) species such as silver fir (Korpel' \& Vinš, 1965; Ellenberg, 2009; Čater et al., 2014). Vaněk and Mauer (2014) noticed that planting of silver fir on large clearing areas is possible, but the vitality and growth of seedlings is lower compared to those cultivated under shelter.

Presently, the dominant species in the region of both sites is Norway spruce and the dominant silviculture system is clear-cutting. With ongoing global climatic change, instability of spruce stands results in high proportion of salvage logging and large-scale calamity events. During the years of our experiment, the precipitation in the Czech Republic was $79 \%$ and $95 \%$ of the long term average (1961-1990) in 2015 and 2016, respectively. The air temperatures were higher by $1.9^{\circ} \mathrm{C}$ and $1.2^{\circ} \mathrm{C}$ than the long term average in the years 2015 and 2016, respectively (CSU, 2018). Changing climate contribute to increased proportion of salvage logging which in recent years usually exceeded $50 \%$ of the total harvest (Zpráva, 2016). To improve tree vitality and forest stability, the forest structure and silviculture systems should change towards more resilient close-to nature management (O’Hara \& Ramage, 2013; Brang et al., 2014), such 
as multi-age or single selection systems. Predictions of the presence and survival of silver fir in the future changing climate at forest types on both sites are controversial (Macias et al., 2006; Lindner et al., 2010; Hlásny et al., 2011; Hanewinkel, 2013). Nevertheless, lower drought sensitivity, higher stability and good wood quality of silver fir can be expected in mixed close-to nature forest structure (Korpel' \& Vinš, 1965; Košulič, 2010; Schütz, 2011; Gazol \& Camarero, 2016). To establish such mixed forest with silver fir in conditions of clearing a nurse crops method is considered as optional solutions (Pommerening \& Murphy, 2004).

Soil conditions on Rakovec were found unfavourable also for artificial regeneration of pioneer species of birch and aspen. To increase the success of artificial regeneration on this kind of site conditions, soil preparation before planting is often recommended (Karlsson, 2002). Deep soil preparation leads to retardation of weed development but brings along an increase in regeneration costs. Contrary to Rakovec, the site conditions at Tornádo represented conditions that are the best for growing birch and aspen as well (Svoboda, 1957; Worrell, 1995). The faster growth birch at this site could be the result of older seedlings of this species used for regeneration, although microsite conditions can be an important factor for growth of young aspen seedlings as shown by the high variability in the height of this species on Tornádo.

Although the height of planted birch on Tornádo was between 2 and $4 \mathrm{~m}$ during the time of the third year of this experiment, no positive impact of this shelter on air temperature was detected. Winter and summer extremes along with the temperature dynamics below the birch shelter $0.5 \mathrm{~m}$ above the ground were similar to the sub-plot without shelter. The same situation was found in the case of Rakovec, where the height of aspen as shelter trees was only $1.5-3 \mathrm{~m}$ at the same time during this experiment. Although the effect of birch shelter on the temperature of air was not evident, the silver fir grew faster under birch compared to those growing on the subplot without the birch shelter of Tornádo. The air was generally well mixed between the rather small forest plots and the main difference in microclimate was probably not in the air but in surface temperatures. Generally, the distance from the forest edge should be over 50 meters to overcome the effect of advection on air temperature (Chen et al., 1999)an outsider. In some cases, the microclimate at the forest edge or in fragmented vegetation may be even more extreme than at the clearing due to lower wind speeds (Chen et al., 1993). Forest canopy is able to lower the maximum air temperatures by only a few degrees. For example, a comparative study of several forest types indicated that maximum air temperatures under the forest canopy were usually no more than $2^{\circ} \mathrm{C}$ lower than at the open plot (Von Arx et al., 2012). The effect of the forest canopy overstory on the surface or soil temperature is greater. The difference in surface soil temperature between the clearing and forest floor frequently reaches over $10^{\circ} \mathrm{C}$ (Chen et al., 1999)an outsider. Similar to that of the soil, the surface temperature of the leaves exposed to the direct sun is frequently more than $10^{\circ} \mathrm{C}$ higher than that of the leaves in the shade (Jones, 2002). High leaf temperature may negatively impact the photosynthesis (Day, 2000; Urban et al., 2017). Together with increased air humidity, the low leaf temperature lowers the vapor pressure difference between leaf and air, and therefore also the evapotranspiration from the sapling in the understorey. Diffuse radiation in the understory enhances light-use efficiency for photosynthesis when compared to direct sun radiation at the clearing (Urban et al., 2007). Maintaining the correct light intensity is the most important issue in the underplanting of a silver fir and other tree species and the light intensity is the most important factor limiting their growth (Robakowski et al., 2004; Dobrowolska, 2006). Also, the nurse effect of birch on silver fir seedlings as a result of the ectomycorrhizal wood-wide-web can be expected (Van Der Heijden \& Marcel, 2004; Simard \& Durall, 2004).

Most of the silver fir seedlings growing under the birch shelter on Tornádo sites can be left without protection against the weed from now on and also protection against browsing is limited. Fast growth of silver fir seedlings in clearing areas is economically profitable due to lower regeneration costs. Also, pioneer species from nurse crop regeneration methods can provide some economic profit (Stark et al., 2015; Unselt \& Bauhus, 2012). At the same time, the nurse crop methods mimic the natural processes (Oliver \& Larson, 1990) and can be acceptable in terms of forest ecology (Pommerening \& Murphy, 2004). The average faster growth of silver fir under birch shelter on Tornádo was accompanied by the high variability in the height of the fir seedlings. This is a good presumption for the creation of a rich vertical structure of the future forest, which is so important for silver fir (Korpel’ \& Vinš, 1965; Schütz, 2011).

The difference in the results of the experiments conducted on Tornádo and Rakovec lead to different regeneration methods depending on the site conditions. At sites with a normal soil moisture regime (as in the case of Tornádo), the regeneration of pioneers and silver fir (climax species) is suitable for sustainable forest management. In the case of periodic influence of the amount of water in the soil (i.e. Rakovec), the regeneration of silver fir should be delayed until the pioneers improve conditions for silver fir regeneration. According to our results this should not happen before the pioneer species are more than $4 \mathrm{~m}$ tall. 


\section{Acknowledgments}

This study was supported by Internal Grant Agency (IGA), a project under the grant LDF_PSV_2018002.

\section{References}

Beljan K, Posavec S, Čavlović J, Teslak K \& Knoke T (2018) Economic consequences of different management approaches to even-aged silver fir forests. Croatian Journal of Forest Engineering 39: 299-312.

Brang P, Spathelf P, Larsen JB, Bauhus J, Bončìna A, Chauvin Ch, Drössler L, García-Güemes C, Heiri C, Kerr G, Lexer MJ, Mason B, Mohren F, Mühlethaler U, Nocentini S \& Svoboda M (2014) Suitability of close-to-nature silviculture for adapting temperate European forests to climate change. Forestry: An International Journal of Forest Research 87: 492-503. doi:10.1093/forestry/ cpu018.

Brzeziecki B \& Kienast F (1994) Classifying the life-history strategies of trees on the basis of the Grimian model. Forest Ecology and Management 69: 167-187.

Cameron AD, Mason WL \& Malcolm DC (2001) Transformation of plantation forests - Papers presented at the IUFRO Conference held in Edinburgh, Scotland, 29 August to 3 September 1999 - Preface. Forest Ecology and Management 151: 1-5. doi:10.1016/S0378-1127(00)00691-5.

Chen J, Franklin JF \& Spies TA (1993) Contrasting microclimates among clearcut, edge, and interior of old-growth Douglas-fir forest. Agricultural and Forest Meteorology 63: 219-237. doi:10.1016/0168-1923(93)90061-L.

Chen J, Saunders SC, Crow TR, Naiman RJ, Brosofske KD, Glen DM, Brookshire BL \& Franklin JF (1999) Microclimate in forest ecosystem and landscape ecology Variations in local climate can be used to monitor and compare the effects of different management regimes. Bioscience 49: 288-297. doi:10.1086/250095.

CSU (2018) Climate of the Czech Republic. https:// www.czso.cz/csu/czso/.

Čater M \& Levanič T (2013) Response of Fagus sylvatica L. and Abies alba Mill. in different silvicultural systems of the high Dinaric karst. Forest Ecology and Management 289: 278-288. doi:10.1016/j. foreco.2012.10.021.

Čater M, Diaci J \& Roženbergar D (2014) Gap size and position influence variable response of Fagus sylvatica L. and Abies alba Mill. Forest Ecology and Management 325: 128-135.

Čermák P \& Holuša O (2011) Forestry adaptation measures at the decline of Norway spruce (Picea abies Karst.) stands as exemplified by the Silesian Beskids, Czech Republic. Acta Universitatis Agriculture et Silviculturae Mendelianae Brunensis 59: 293-302.

Day ME (2000) Influence of temperature and leafto-air vapor pressure deficit on net photosynthesis and stomatal conductance in red spruce (Picea rubens). Tree Physiology 20: 57-63. doi:10.1093/ treephys/20.1.57.

Dobrowolska D (2006) Oak natural regeneration and conversion processes in mixed Scots pine stands. Forestry 79: 503-513. doi:10.1093/forestry/ cpl034.

Dobrowolska D, Bončina A \& Klumpp R (2017) Ecology and silviculture of silver fir (Abies alba Mill.): a review. Journal of Forest Research 22: 326-335. doi:10.1080/13416979.2017.1386021.

Dube S \& Plamondon AP (1995) Relative importance of interception and transpiration changes causing watering-up after clearcutting on four wet sites. IAHS Publications-Series of Proceedings and Reports-Intern Assoc Hydrological Sciences 230: 113-120.

Ellenberg H (2009) Vegetation ecology of central Europe. 4th ed. Cambridge, Cambridge University Press, New York, USA.

Elling W, Dittmar C, Pfaffelmoster K \& Rötzer T (2009) Dendroecological assessment of the complex causes of decline and recovery of the growth of silver fir (Abies alba Mill.) in Southern Germany. Forest Ecology and Management 257: 1175-1187.

Fanta J (1997) Rehabilitating degraded forests in Central Europe into self-sustaining forest ecosystems. Ecological Engineering 8: 289-297.

Gazol A \& Camarero JJ (2016) Functional diversity enhances silver fir growth resilience to an extreme drought. Journal of Ecology 104: 1063-1075. doi:10.1111/1365-2745.12575.

Hanewinkel M, Cullman DA, Schelhaas MJ, Nabuurs GJ \& Zimmermann NE (2013) Climate change may cause severe loss in the economic value of European forest land. Nature Climate Change 3: 203-207. doi: 10.1038/NCLIMATE1687.

Hlásny T, Barcza Z, Fabrika M, Balász B, Churkina G, Pajtík J, Sedmák R \& Turčáni M (2011) Climate change impacts on growth and carbon balance of forests in Central Europe. Climate Research 47: 219-236.

Hlásny T, Mátyás C, Seidl R, Kulla L, Merganičová K, Trombik J, Dobor L, Barcza Z \& Konôpka B (2014) Climate change increases the drought risk in Central European forests: what are the options for adaptation? Lesnícky časopis - Forestry Journal 60: 5-18.

Hurt V \& Mauer O (2016) Podsadby přípravných porostů břízy bělokoré, olše a jeřábu ptačího bukem lesním a jedlí bělokorou: certifikovaná metodi- 
ka (osvědčení 69254/2016-MZE-16222/M129). Mendelova univerzita v Brně, Brno, Czech Republic.

IUSS Working Group WRB (2014) World Reference Base for Soil Resources 2014. International soil classification system for naming soils and creating legends for soil maps. World Soil Resources Reports No. 106. FAO, Rome.

Jones HG (2002) Use of infrared thermography for monitoring stomatal closure in the field: application to grapevine. Journal of Experimental Botany 53: 2249-2260. doi:10.1093/jxb/erf083.

Kacálek D, Mauer O, Podrázský V \& Slodičák M (2017) Meliorační a zpevňující funkce lesních dřevin (Soil improving and stabilizing functions of forest trees). Lesnická práce, Kostelec nad Černými lesy, Czech Republic.

Kantor P (2001) Obnova jedle bělokoré: Pěstování a umělá obnova jedle bělokoré (ed. by K Kotrla \& P Kyslík) AVE Centrum, Chudobín u Litovle, Czech Republic, pp. 5-13.

Karlsson A (2002) Site preparation of abandoned fields and early establishment of planted smallsized seedlings of silver birch. New Forests 23: 159-175.

Klimatická změna (2018) http://www.klimatickazmena.cz/en/.

Korpel' Š \& Vinš B (1965) Pestovanie jedle. SVLP, Bratislava, Slovakia.

Košulič M (2010) Cesta k přírodě blízkému hospodářskému lesu. FSC ČR, Brno, Czech Republic.

Lindner M, Maroschek M, Netherer S, Kremer A, Barbati A, Garcia-Gonzalo J, Seidl R, Delzon S, Corona P, Kolström M, Lexer MJ \& Marchetti M (2010) Climate change impacts, adaptive capacity, and vulnerability of European forest ecosystems. Forest Ecology and Management 259: 698-709. doi:10.1016/j.foreco.2009.09.023.

Macias M, Andreu L, Bosch O, Camarero JJ \& Guitierrez E (2006) Increasing aridity is enhancing fir (Abies alba Mill.) water stress in its south-western distribution limit. Climatic Change 76: 289-313. doi:10.1007/s10584-006-9071-0.

Martiník A, Dobrovolný L \& Hurt V (2014) Comparison of different forest regeneration methods after windthrow. Journal of Forest Science 60: 190-197.

Martiník A \& Dušek D (2015) Potenciál mladších jedlových porostů (Abies alba Mill.) k přirozené obnově pod chřadnoucím smrkem na severní Moravě. Zprávy lesnického výzkumu 60: 267-273.

Málek J (1983) Problematika ekologie jedle bělokoré a jejího odumírání. 1st ed. Academia, Praha, Czech Republic.

Motta R (1996) Impact of wild ungulates on forest regeneration and tree composition of mountain forests in the western Italian Alps. Forest Ecology and Management 88: 93-98. doi:10.1016/S03781127(96)03814-5.

O’Hara KL (2014) Multiaged silviculture - managing for complex forest stand structures. Oxford university Press, New York, USA.

O'Hara KL \& Ramage BS (2013) Silviculture in an uncertain world: utilizing multi-aged management systems to integrate disturbance. Forestry: An International Journal of Forest Research 86: 401-410. doi:10.1093/forestry/cpt012.

Oliver ChD \& Larson BC (1990) Forest stand dynamics. McGraw-Hill, New York, USA.

Plíva K \& Průša E (1969) Typologické podklady pěstování lesů. SZN, Praha, Czech Republic.

Poleno Z \& Vacek S (2007) Pěstování lesů II. - Teoretická východiska pěstování lesů. Lesnická práce, Kostelec nad Černými lesy, Czech Republic.

Pommerening A (2006) Transformation to continuous cover forestry in a changing environment. Forest Ecology and Management 224: 227-228. doi:10.1016/j.foreco.2005.12.036.

Pommerening A \& Murphy ST (2004) A review of the history, definitions and methods of continuous cover forestry with special attention to afforestation and restocking. Forestry 77: 27-44.

R Development Core Team (2017) R: A language and environment for statistical computing. R Foundation for Statistical Computing, Vienna, Austria. http://www.R-project.org/.

Robakowski P, Wyka T, Samardakiewicz S \& Kierzkowski D (2004) Growth, photosynthesis, and needle structure of silver fir (Abies alba Mill.) seedlings under different canopies. Forest Ecology and Management 201: 211-227. doi:10.1016/j. foreco.2004.06.029.

Seitschek O (1991) Waldbauliche Möglichkeiten auf Kahlflächen unter besonderer Berücksichtigung der Vorwaldbaumarten. Forst und Holz 46: 351355.

Senn J \& Suter W (2003) Ungulate browsing on silver fir (Abies alba) in the Swiss Alps: beliefs in search of supporting data. Forest Ecology and Management 181: 151-164. doi:10.1016/S0378$1127(03) 00129-4$.

Schelhaas MJ (2008) Impacts of natural disturbances on the development of European forest resources: application of model approaches from tree and stand levels to large-scale scenarios. The Finnish Society of Forest Science, Helsinki, Finland.

Schütz JP (2011) Výběrné hospodářství a jeho různé formy. Lesnická práce, Kostelec nad Černými lesy, Czech Republic.

Simard SW \& Durall DM (2004) Mycorrhizal networks: a review of their extent, function, and importance. Canadian Journal of Botany 82: 11401165. 
Spiecker H, Hansen J, Klimo E, Skovsgaard JP, Sterba H \& von Teuffel K (2004) Norway spruce conversion: Options and consequences. European Forest Institute, Research report 18. Brill Academic Publishers, Leiden, the Netherlands.

Stark H, Nothdurft A, Block J \& Bauhus J (2015) Forest restoration with Betula ssp. and Populus ssp. nurse crops increases productivity and soil fertility. Forest Ecology and Management 339: 57-70.

Svoboda P (1957) Lesní dřeviny a jejich porosty. Část III. SZN, Praha, Czech Republic.

Šindelář J \& Frýdl J (2005) Perspektivy jedle bělokoré (Abies alba Mill.) v lesním hospodárství České republiky: Jedle bělokorá - 2005: European silver fir - 2005 (ed. by P Neuhöferová) Lesnická práce, Kostelec nad Černými lesy, Czech Republic, pp. 163-168.

Unselt R \& Bauhus J (2012) Energie-Vorwälder - Alternative Bewirtschaftungsformen zur Steigerung der energetisch nutzbaren Biomasse im Wald durch Integration von schnell wachsenden Baumarten. Schriftenreihe Freiburger Forstliche Forschung, Freiburg, Germany.

Urban J, Ingwers MW, McGuire MA \& Teskey RO (2017) Increase in leaf temperature opens stomata and decouples net photosynthesis from stomatal conductance in Pinus taeda and Populus deltoides $x$ nigra. Journal of Experimental Botany 68: 17571767. doi:10.1093/jxb/erx052.

Urban O, Janouš D, Acosta M, Czerný R, Marková I, Navrátil M, Pavelka M, Pokorný R, Šprtová M, Zhang R, Špunda V, Grace J \& Marek MV (2007) Ecophysiological controls over the net ecosystem exchange of mountain spruce stand. Comparison of the response in direct vs. diffuse solar radiation. Global Change Biology 13: 157-168.

Van der Heijden \& Marcel GA (2004) Arbuscular mycorrhizal fungi as support systems for seedling establishment in grassland. Ecology Letters 7: 293303. doi:10.1111/j.1461-0248.2004.00577.x.

Vaněk P \& Mauer O (2014) Regeneration of Silver fir (Abies alba Mill.) on Clear-cut Areas. Acta Universitatis Agriculture et Silviculturae Mendelianae Brunensis 62: 267-277.

Viewegh J, Kusbach A \& Mikeska M (2003) Czech forest ecosystem classification. Journal of Forest Science 49: 85-93.

Von Arx G, Dobbertin M \& Rebetez M (2012) Spatio-temporal effects of forest canopy on understory microclimate in a long-term experiment in Switzerland. Agricultural and Forest Meteorology 166: 144-155. doi:10.1016/j.agrformet.2012.07.018.

Vrška T, Adam D, Hort L, Koláŕ T \& Janík D (2009) European beech (Fagus sylvatica L.) and silver fir (Abies alba Mill.) rotation in the Carpathians - a developmental cycle or linear trend induced by man? Forest Ecology and Management 258: 347356.

Worrell R (1995) European aspen (Populus tremula L): a review with particular reference to Scotland II. Values, silviculture and utilization. Forestry 68: 231-243.

Zlatník A (1976) Lesnícka fytocenologie. SZN, Praha, Czech Republic.

Zpráva (2016) Zpráva o stavu lesa a lesního hospodářství České republiky 2016. Praha, Ministerstvo zemědělství ĆR. http://eagri.cz/public/ web/mze/lesy/lesnictvi/zprava-o-stavu-lesa-a-lesniho/zprava-o-stavu-lesa-a-lesniho-2016.html. 